\title{
Landowners' Responses to an Endangered Species Act Listing and Implications for Encouraging Conservation
}

\author{
AMARA BROOK, ${ }^{*}$ MICHAELA ZINT, AND RAYMOND DE YOUNG \\ School of Natural Resources \& Environment, University of Michigan, Dana Building, 430 East University, \\ Ann Arbor, MI 48109-1115, U.S.A.
}

\begin{abstract}
Private landowners manage many rare species' habitats, yet research on their responses to species conservation legislation is scarce. To address this need, we examined private landowners' responses to the listing of the Preble's meadow jumping mouse (Zapus hudsonius preblei) as threatened under the U.S. Endangered Species Act (ESA). We mailed a questionnaire designed to measure these responses to a sample of landowners. The adjusted response rate was $46 \%(\mathrm{n}=379)$. The questionnaire asked landowners whether they had managed their land to improve the Preble's habitat and to minimize the chance of the Preble's living on it. We also asked whether landowners had or would allow a survey for the Preble's on their property. We bypothesized that landowners would respond to these questions based on their aesthetic preferences, economic concerns, information sources, parcel size, personal values, recreation activities, residence status, social influences, and other factors. Listing the Preble's under the ESA does not appear to have enhanced its survival prospects on private land. In terms of hectares owned, for example, the efforts of landowners who reported they bad sought to belp the Preble's (25\%) were canceled out by the efforts of those who sought to harm it (26\%). Moreover, the majority of respondents had not or would not allow a biological survey (56\%), thus preventing the collection of data for conserving the species. All eight bypothesized determinants significantly predicted responses to the listing when they were considered individually. When considered simultaneously, bowever, only one economic consideration (dependence on agriculture), recreation activity (consumptive), and social factor (distrusting government), and select information sources (conservation and social), and personal values (valuing nature, valuing local control, and denying landowner responsibility) remained direct determinants. To promote the conservation of rare species by private landowners, we recommend communicating information through social networks, alleviating landowners' economic concerns, increasing use of collaborative processes, and institutionalizing assurances that landowners will not be harmed by managing their land to belp rare species.
\end{abstract}

Respuestas de Terratenientes a un Listado Relacionado al Acta de Especies en Peligro y Sus Implicaciones para Promover la Conservación

Resumen: Propietarios privados manejan el hábitat de muchas especies raras, sin embargo son escasas las investigaciones sobre sus respuestas a la legislación sobre conservación de especies. Para atender esta necesidad, examinamos las respuestas de propietarios privados a la inclusión del ratón de Preble (Zapus hudsonius preblei) en la lista de especies amenazadas según el Acta de Especies en Peligro (AEP) de E.U. A. Para medir estas respuestas, enviamos por correo un cuestionario a una muestra de terratenientes. La tasa ajustada de respuesta fue $46 \%(\mathrm{n}=379)$. El cuestionario le preguntaba a los terratenientes si habian manejado sus terrenos para mejorar el hábitat del ratón de Preble o para minimizar la probabilidad de que los ratones vivan en él. También preguntamos si los terratenientes permitieron o permitirín un muestreo de ratones en sus

\footnotetext{
${ }^{*}$ Current address: Department of Psychology, University of Michigan, 525 East University, Ann Arbor, MI 48109-1109, U.S.A., email abrook@umich.edu

Paper submitted June 12, 2002; revised manuscript accepted March 11, 2003.
}

1638 
propiedades. Nuestra bipótesis fue que los propietarios responderían a estas preguntas según sus preferencias estéticas, preocupaciones económicas, fuentes de información, tamaño de parcelas, valores personales, actividades recreativas, estatus residencial, influencias sociales y otros factores. Aparentemente, la inclusión del ratón de Preble en el AEP no ba incrementado su probabilidad de supervivencia en tierras privadas. Por ejemplo, en términos de bectáreas posé́das, los esfuerzos de propietarios que informaron haber tratado de ayudar al ratón (25\%) fueron cancelados por los esfuerzos de los que trataron de dañarlo (26\%). Más aun, la mayoría de los respondientes no babían permitido ni permitirían un muestreo biologico (56\%), evitando así la recolección de datos para conservar a la especie. Considerados individualmente, las ocho determinantes hipotéticas predijeron respuestas significativas a la inclusión de la especie. Sin embargo, consideradas simultáneamente, solo permanecieron como determinantes directas la dependencia en la agricultura (consideración económica), la actividad recreativa (de consumo), la desconfianza en el gobierno (factor social), las fuentes de información selectas (conservación y social) y los valores personales (valoración de la naturaleza, valoración del control local y negación de la responsabilidad de propietarios). Para promover la conservación de especies raras por propietarios privados recomendamos informar a través de redes sociales, aligerar las preocupaciones económicas de los propietarios, incrementar el uso de procesos colaborativos e institucionalizar la certidumbre de que los propietarios no serían perjudicados por manejar sus tierras para favorecer a especies raras.

\section{Introduction}

Conservation biologists recognize that private-property owners' actions play a critical role in determining to what extent species conservation goals will be met (Bean \& Wilcove 1997; James 2002). This is because many rare species rely on habitat provided by private land for their survival. In the United States, for example, more than $90 \%$ of federally listed species have some habitat on nonfederal land, and 37-50\% depend entirely on nonfederal land (U. S. General Accounting Office 1994; Stein et al. 1995).

The U.S. Fish and Wildlife Service has relied on the U.S. Endangered Species Act (ESA) to conserve rare species found on private land (Fisher 1996; Wilcove et al. 1996). The assumption has been that listing endangered species under the act will help protect them on private land. Some have suggested, however, that fear of possible land-use restrictions may lead private property owners to eliminate the species from their land (Wilcove et al. 1996). Such actions may include unlawfully and directly harming the species and legally but harmfully avoiding habitat improvements or managing land to keep threatened and endangered species away. So far, however, these claims have been based on speculation and anecdote (Honnold et al. 1997).

If the ESA regulatory approach does not adequately encourage conservation on private land, what else can be done to preserve rare species? Although empirical research on rare-species conservation by private landowners is sparse, many studies of landowners' practices in other conservation contexts, such as agricultural conservation, have identified factors that may be important targets for intervention. Landowners' conservation decisions have, for example, been influenced by aesthetic preferences, economic considerations, information (e.g., sources, amount), parcel size, personal values, recreation activities, residence (i.e., living on the land), and social factors.

More specifically, aesthetic preferences for views of nature, animals, and forests have been associated with adopting land-conservation practices (Benson 1991; Erickson \& De Young 1993), whereas other preferences, such as for a clean, tidy landscape, have worked against adopting conservation practices (Carr \& Tait 1991). In accordance with economic theory (Tietenberg 2000), previous research suggests that land conservation is more likely to occur when it is perceived to have monetary benefits (Makowski et al. 1990; Benson 1991) and less likely when perceived to have monetary costs (Carr \& Tait 1991; McCann et al. 1997). Information from sources with a conservation focus (e.g., wildlife agencies) has encouraged land conservation (Korsching \& Hoban 1990), whereas reliance on sources whose interests may conflict with conservation (e.g., farm supply companies) or a lack of information altogether has discouraged conservation (Osterman \& Hicks 1988; Grieshop et al. 1990). Parcel size may encourage conservation if large landowners believe their actions are more important or they can afford to take more risks (Fortmann \& Huntsinger 1989), or it may discourage conservation if large landowners believe they have more to lose (McCann et al. 1997).

Personal values can either encourage or discourage land conservation. Valuing environmental protection (Vogel 1996), ecological and environmental stewardship (Ochterski 1996), agrarian stewardship (Peterson \& Horton 1995), and "preserving a way of life," and experiencing intrinsic satisfaction from conservation all render conservation action more likely (Erickson \& De Young 1993). Conversely, if people believe in private property rights, they are likely to be hostile to outside intervention on land-management issues (Napier \& Camboni 1988; Reading et al. 1994). Landowners holding such beliefs may, however, have high confidence in their 
land-management abilities and may practice conservation of their own volition (Peterson \& Horton 1995).

Both nonconsumptive recreational activities such as wildlife viewing and hiking and consumptive activities such as hunting and fishing are expected to lead to the adoption of conservation practices (for a review see Theodori et al. 1998), although some have argued that those engaging in consumptive recreation only act to protect game species (Holsman 2000). Research also indicates that recreation interests may motivate nonindustrial private forest owners to maintain woodlots (Bliss \& Martin 1989) and adopt management practices to benefit wildlife (Haymond 1990), although one study found that, when attitudes toward the forest and sociodemographic characteristics are controlled for, recreational activities did not predict management practices (Bourke \& Luloff 1994). Resident landowners may be more likely to conserve than nonresidents because they may be more familiar with their land and have more opportunity to enjoy the benefits of their efforts (Fortmann \& Huntsinger 1989). Land conservation is more likely to occur when supported by social norms (West et al. 1988; Sullivan et al. 1996). Conflict and mistrust between conservation agencies and landowners especially discourages conservation (Peterson \& Horton 1995).

To learn about private landowners' responses to ESA listings specifically, we focused on the threatened Preble's meadow jumping mouse (Zapus budsonius preblei), which was listed in May 1998 (U.S. Fish and Wildlife Service 1998a; Brook 1999). We examined this particular species because its survival depends heavily on habitat found on private land (Brook 1999, unpublished data). One of our goals was to assess the impact of this species listing on private landowners' decisions and thus on the conservation of the species. Another was to identify predictors of landowners' responses with the aim of helping practitioners encourage the conservation of rare species on private land.

\section{Method}

We conducted our study in two stages. First, we held open-ended interviews with 13 landowners in June 1998 to determine how they responded to the listing of the Preble's meadow jumping mouse and to identify which variables may explain their responses. Based on prior research and these interviews, we next developed a standardized questionnaire.

Using this instrument, we asked, "On a scale of 1 to 5 , please indicate the extent to which you, yourself have taken the following actions in response to the Preble's listing." Embedded in the subsequent list of 10 actions were two behaviors that had the potential to affect the Preble's mouse directly: the extent to which landowners had managed their land to (1) help ("managed your land to improve Preble's habitat") or (2) harm ("managed your property to minimize the chance of the Preble's living on it") the Preble's, which they indicated on a scale of 1 , "not at all," to 5, "to a great extent." To minimize the perceived threat of answering the "harm" question, to elicit more honest responses, and to reduce the likelihood of refusal to respond, we used only one item to assess each of these two behaviors. For the same reasons, we also omitted items that specifically asked how respondents had sought to harm the Preble's. We recognize the limitation of using only two general items but believe that the trade-off was necessary to elicit complete and honest responses.

To examine the construct validity of these two questions, we also asked about the extent to which respondents had engaged in specific land-management practices that could benefit or harm the Preble's. For the reasons mentioned previously, however, the Preble's was not explicitly referenced in this question ("To what extent do you use the following management practices?"), and we asked about practices both related (e.g., constructing wetlands) and unrelated (e.g., modifying fences to allow wildlife migration) to the Preble's. Responses were on a scale of 1, "not at all," to 5, "to a great extent," and respondents could also indicate "don't know."

We also asked participants whether anyone had contacted them requesting permission to survey for the Preble's on their land ("Has anyone contacted you requesting permission to survey [look or trap] for the Preble's mouse on your land?"). If so, we asked, "Did you allow them to survey?" If they had not been contacted, we asked, "If someone asked for your permission to survey for the Preble's mouse on your land, would you grant them permission?"

The scales used to measure the predictors of landowners' responses to the listing were written in language used by our study population during the interviews (Table 1). For two reasons, we chose not to use standard scales such as the New Environmental Paradigm Scale (Dunlap \& Van Liere 1978). First, we were concerned that measures used by this and similar scales would be considered objectionably "environmentalist" by conservative landowner respondents. And second, more specific measures have been found to better predict behaviors than general measures (Kraus 1995). Because many of these scales were new, we constructed them by using a combination of theory, exploratory factor analysis (principal axis with direct oblimin rotation), and reliability analyses. The reliabilities of most of the scales were acceptable (Green et al. 2000), ranging from $\alpha=0.50$ to $\alpha=0.91$ (Table 1 ).

Once pilot-tested, the questionnaire was mailed to a stratified, clustered-random-probability sample of 833 owners of Preble's habitat in March 1999, 10 months after the listing of the Preble's as threatened. This sample comprised approximately $50 \%$ of the entire population of owners of Preble's habitat. Habitat areas sampled were 
Table 1. Reliability of items included in scales used to predict landowners' responses to the listing of the Preble's meadow jumping mouse (Zapus budsonius preblei) as a threatened species.

Aesthetic preferences

(1) "creating an organized landscape" is important in land-management decisions

(2) "maintaining or enhancing the beauty of your land" is important in land-management decisions

Economic dependence on agriculture

(1) belief that farming is important to my economic well-being

(2) belief that ranching is important to my economic well-being

(3) use land for farming

(4) use land for ranching

Economic dependence on real estate

(1) real estate development is important to my economic well-being

(2) have plans to possibly develop land in future

(3) use land for investment

(4) use land for real estate development

Economic dependence on mining

(1) mining is important to my economic well-being

(2) use land for mining.

General economic concern

(1) financial security is important in land-management decisions

(2) making a profit is important in land-management decisions

(3) agree that "I am concerned about my family's financial welfare."

Disagree that "Landowners should bear financial responsibility for achieving public conservation goals on their land." Off-land income

Income

Information from conservation agencies and organizations

(1) amount of information received from Colorado Division of Wildlife

(2) amount of information received from U.S. Fish and Wildlife Service

(3) amount of information received from private conservation organizations

Information from agricultural agencies and organizations

(1) amount of information received from Farm Bureau

(2) amount of information received from Colorado Cattlemen's Association

(3) amount of information received from agricultural extension (e.g., Colorado State University Extension Service)

(4) amount of information received from local soil conservation district/Natural Resources Conservation Service

Information from social sources (family, friends)

(1) amount of information received from family

(2) amount of information received from friends and neighbors.

Information from mass media

(1) amount of information received from media (e.g., television, radio)

(2) amount of information received from newspapers

Parcel size (log acres)

Species bias

(1) disagree that "The Preble's meadow jumping mouse is worth protecting."

(2) agree that "I am more interested in protecting species I see often than those I have never seen."

(3) agree that "All rodents are a nuisance."

Value local control

(1) agree that "Landowners, rather than the government, should have the final authority to make conservation decisions on their land."

(2) agree that "State and local governments, not the federal government, should have the final authority on threatened species issues."

(3) agree that "Landowners are good stewards of their land."

Disagree that "Landowners should be responsible for conserving rare species on their land."

Value nature

(1) agree that "Conserving wildlife is important to me."

(2) agree that "I enjoy having wildlife on my land."

(3) agree that "Water quality is a top consideration in my land management."

(4) "conserving wildlife" is important in land-management decisions

(5) "conserving rare plants" is important in land-management decisions

(6) "protecting water resources" is important in land-management decisions

Nonconsumptive recreation

(1) use land for hiking

(2) use land for horseback riding

(3) use land for wildlife viewing 
Table 1. (continued)

(1) use land for fishing

(2) use land for hunting

(3) "maintaining hunting opportunities" is important in land-management decision-making

Residence (i.e., living on the land)

Social influence

(1) "benefiting your community" is important in land-management decisions

(2) "opinions of family" are important in land-management decisions

(3) "opinions of friends and neighbors" are important in land-management decisions

Distrust government

(1) agree that "I don't trust the federal government."

(2) disagree that "I trust my Natural Resources Conservation Service agent."

(3) disagree that "I trust U.S. Fish and Wildlife service personnel."

View government as unfair: disagree that "I believe federal agencies are fair in dealing with private landowners."

Government does not value opinion

(1) disagree that "Local government officials value my opinion."

(2) disagree that "State and federal government officials value my opinion."

based on the U.S. Fish and Wildlife Service's best estimate of Preble's habitat areas at the time our sample was selected. These areas were announced in the proposed 4(d) rule issued 3 December 1998 (U.S. Fish and Wildlife Service $1998 b$ ) but were not codified in the final rule because of concerns that they were based on inadequate information and amounted to designation of critical habitat without proper procedure (U.S. Fish and Wildlife Service 2001). Critical habitat has since been proposed (U.S. Fish and Wildlife Service 2002) but does not exactly correspond to our sampling area because of different criteria for designating critical habitat and because of additional biological information collected since the time the original habitat areas were proposed. Our sample, however, represents the U.S. Fish and Wildlife Service's best estimate of Preble's habitat areas at that time, and there is considerable overlap between these areas and the critical habitat areas proposed more recently.

Because the nine counties (seven in Colorado, two in Wyoming) in our sampling area vary in rural character and state and county government characteristics, the sample was first proportionally stratified by county. Within each county, the sample was then clustered by section. Half the sections containing Preble's habitat in each county were randomly sampled, and all private landowners whose property contained Preble's habitat within the sampled sections were then mailed surveys. We used habitat as the sampling unit rather than individual landowners because maps of habitat were available for the entire range of the Preble's, but there was no list of landowners with Preble's habitat. A precursor postcard, questionnaire, and follow-up postcard resulted in a $46 \%(n=379)$ response rate, after invalid addresses were adjusted for. This sample size should produce a sampling error of less than $\pm 5 \%$ (Kalton 1983). We believe that our response rate is high given the sensitivity of the topic, the length (13 pages) of the questionnaire, and the survey being administered by mail with only three contacts (Salant \& Dillman 1994). The high salience of this topic probably contributed to this response rate.

We are aware that nonresponse bias is possible and suspect that nonrespondents differed from respondents in some of the following ways. Nonrespondents may have known less about the listing of the Preble's and its implications and thus may have felt unqualified to respond. Nonrespondents may have been busier, with possible implications for land-management practices. Or, nonrespondents may have been more worried and fearful that participation, even though it was anonymous, could have negative consequences. Although we were unable to conduct a survey of nonrespondents, we examined how they differed from individuals in the nine sampled counties based on 1990 census data. Respondents were older, were more likely to be male, educated, and wealthy, and were more likely to have an agricultural occupation. Although our sample thus differed from the population of the counties, it is representative of landowners (Weicher 1995).

Because two of the dependent variables of interest had Poisson distributions-many people had not engaged in behaviors to help or harm the mouse-they were dichotomized before they were used in logistic regression analyses (Lepkowski \& Couper 1999).

\section{Results}

Only one interviewed landowner had changed his landmanagement practices to benefit the Preble's meadow jumping mouse. The rest continued their prior management activities. None said he or she had managed land to the detriment of the Preble's. However, of the five landowners who had been asked to allow a survey (i.e., looking for or trapping of the Preble's), $60 \%$ refused, explaining they did so as a means to protect themselves from 
having their land regulated. Other responses the landowners had to the Preble's listing were discussing the issue with neighbors or friends, attending public meetings, contacting government officials, and consulting with attorneys. The results of the interviews suggested that aesthetic preferences, economic considerations, information sources, recreational activities, social factors, personal values, residence status (i.e., living on the land), and parcel size may have played a role in determining landowners' responses to the species listing. The interviews also suggested that many landowners considered allowing surveying to be a great risk because data collected could possibly be used to regulate their property and because many did not trust the government or conservation organization biologists who would be conducting the survey. In the interviews, landowners indicated that they refused to allow surveying for these reasons, and we expected this also to be the case for the landowners included in our survey.

The majority of survey respondents had heard of the Preble's meadow jumping mouse before receiving the questionnaire (84\%). However, less than half were certain that their property was in an area designated for regulation to protect it (45\%), whereas an almost equal percentage were unsure whether their property was in a protected area (43\%), and only $12 \%$ mistakenly thought that their land was outside a protected area. There were some differences between these landowners. Compared with landowners who were unsure whether their land was in a protected area, landowners who were sure their land was in a protected area were almost three times as likely to have helped the Preble's by improving its habitat, $(\operatorname{Exp}(B)$ $=2.96, p<0.01$ ), over twice as likely to have harmed the Preble's by managing their property to minimize the chance of the Preble's living on it $(\operatorname{Exp}(B)=2.42, p<$ 0.05 ), but equally likely to allow a survey for the Preble's on their land $(\operatorname{Exp}(B)=0.70, p=0.19)$. Compared with landowners who thought that their land was outside a protected area, landowners who knew their land was inside a protected area were over three times as likely to have helped the Preble's $(\operatorname{Exp}(B)=3.50, p<0.05)$ but equally likely to have harmed the Preble's $(\operatorname{Exp}(B)=$ $1.29, p=0.63)$ or to allow a survey $(\operatorname{Exp}(B)=1.33$, $p=0.49$ ). Landowners who were unsure whether their land was in a protected area and those who thought that their land was outside a protected area were equally likely to have helped the Preble's, $(\operatorname{Exp}(B)=1.18, p=0.78)$, to have harmed the Preble's $(\operatorname{Exp}(B)=0.53, p=0.29)$, or to allow a survey $(\operatorname{Exp}(B)=1.89, p=0.13)$. Thus, landowners who knew their land was in a protected area were more likely than other landowners to have helped the Preble's, and more likely than landowners who were unsure whether their land was in a protected area to have harmed the Preble's. However, all three groups of landowners were equally likely to allow a survey. The effects of other predictors on the dependent variables dif- fered in significance but not direction across these three groups of landowners, so all landowners were included in the analyses.

\section{Landowner Responses to the Preble's Listing}

Less than one-third of landowners (29\%) reported making any land-management changes in response to the Preble's listing: $22 \%$ managed their property to improve the Preble's habitat and $14 \%$ to minimize the chance of the Preble's living on it. A few reported managing their property for both purposes (7\%), and answers to these two questions were positively but weakly correlated $(r=0.29, p<$ 0.001 ). It is possible that this overlap is partially the result of these landowners misinterpreting the "improving habitat" question to mean changing the Preble's habitat for their own real estate or agricultural purposes, rather than to benefit the mouse. If this is true, then our estimates of the proportion of landowners who actually managed their land to help the Preble's are somewhat high.

Based on number of hectares owned, $43 \%$ of the land experienced some management change in response to the Preble's listing. This percentage of land area that had undergone management change is larger than the percentage of landowners who made management changes (29\%), suggesting that larger landowners were more likely to have made changes than smaller ones. In terms of area, $25 \%$ of the land had been managed to improve Preble's habitat, $26 \%$ to minimize the chance of the Preble's living on it, and $8 \%$ for both purposes. Thus, although a smaller percentage of landowners managed their property to minimize the chance of the Preble's living on it than to improve Preble's habitat, the percentage of land managed to the detriment of the Preble's was about equal to the percent managed to help it. Assuming a similar quality of habitat, this suggests that the efforts of landowners who acted to help the Preble's were cancelled by those who sought to harm it. If the $8 \%$ of habitat reported to have been managed for both purposes reflected landowners misinterpreting the "improving habitat" question, then the proportion of land managed to harm the Preble's may be greater than the proportion managed to help it.

The questions about helpful versus harmful behavior correlated with specific land-management practices that could benefit or harm the Preble's. For example, managing to improve Preble's habitat was positively correlated with constructing wetlands $(r=0.28, p<0.001)$, using holistic resource management $(r=0.33, p<0.001)$, and planting trees $(r=0.25, p<0.001)$, whereas managing to eliminate the mouse was positively correlated with grazing cattle $(r=0.18, p<0.01)$ and haying $(r=0.18$, $p<0.01$ ).

Landowners also responded to the Preble's listing in several other ways. Almost three-quarters of respondents discussed the listing with neighbors or friends (74\%). In addition, about one-third of respondents attended 
public meetings on the listing (29\%). Other responses included writing or calling government officials regarding the listing (19\%), consulting with government agencies $(17 \%)$ or conservation organizations $(17 \%)$ about how to manage for the Preble's, hiring legal counsel (7\%), applying for a permit to carry out a regulated activity (7\%), and hiring someone to conduct a survey for the Preble's (5\%).

Lastly, relatively few respondents had been asked for permission to survey their land for the Preble's (18\%). Of these, a majority had given it (61\%). Of those who had not been asked, a smaller percentage indicated that they would allow surveying (40\%). A significantly higher proportion of respondents (binomial test; $p<0.05$ ) said they had not or would not give permission to allow a biological survey (56\%) than said they had or would (44\%).

\section{Understanding Landowner Responses to the Preble's Listing}

Individually, one or more dimensions of aesthetic preferences, economic considerations, information sources, parcel size, personal values, recreational activities, residence, and social factors significantly predicted which landowners managed to improve the Preble's habitat, managed their land to minimize the chance of the species living on it, and allowed surveying for the Preble's on their land (Table 2). When predictors significant in the simple regressions were entered into multiple logistic regression, fewer remained significant. Specifically, the more information landowners received from conservation organizations or family, friends, or neighbors (i.e., social sources) and the more they valued nature, the more likely they were to manage to improve the Preble's habitat. The more economically dependent they were on agriculture, the more information landowners had received about the Preble's from family, friends, or neighbors, and the more they denied that landowners should be responsible for species conservation, the more likely they were to manage their land to minimize the chance of the Preble's living on it. The more landowners valued local control over land management, engaged in consumptive recreation, and distrusted government, the less likely they were to allow surveying for the Preble's on their land. The more landowners valued nature, however, the more likely they were to allow surveying.

Significant variables in the simple regressions that dropped out of the multiple regressions appeared to do so because they were highly correlated with one or more of the stronger remaining predictors (Table 3 ). For example, aesthetic preferences individually were a strong predictor of management to improve habitat but did not remain significant in the multiple regression because of their high correlation with valuing nature. Similarly, general economic concern did not remain significant in the multiple regressions predicting management to minimize the chance of the Preble's living on land or refusing to allow surveying, possibly because this variable was highly cor- related with economic dependence on agriculture, valuing local control, denying landowner responsibility for conservation, engaging in consumptive recreation, and distrusting government. Results for the other variables significant in the simple but not the multiple regressions were similar.

\section{Discussion}

Altogether, private landowners' responses suggested that the current regulatory approach to the conservation of rare species is insufficient to protect the Preble's mouse. Not all property owners with land containing Preble's habitat had heard of the species, and many were unsure whether their property was within its range and could thus be regulated. Additionally, for this particular species, the previously untested assertion that some landowners may act to harm rare species on their property was supported. Such a negative response to an intervention designed to protect rare species is cause for concern. In the case of the Preble's, our results suggest that landowners' detrimental actions cancelled out the efforts of landowners seeking to help the species. As more landowners become aware that their land contains Preble's habitat, it is likely that the impact on the species may be negative.

Many landowners appeared to defend themselves against having their land-management options restricted by refusing to allow surveys for the Preble's. Such actions do not directly harm rare species, but they do prevent researchers from learning about their distribution and abundance. Without this information, formulating conservation plans is difficult, and those that are formed may be inaccurate, perceived as illegitimate, or challenged in the courts because of a lack of supporting data (U.S. Fish and Wildlife Service 1998a). In fact, the U.S. Fish and Wildlife Service's first attempt to officially delineate habitat areas for the Preble's did not survive public scrutiny as a result of such a lack of data (U.S. Fish and Wildlife Service 2001).

Research is needed to assess the extent to which the findings from our study can be generalized to other endangered and threatened species, particularly more popular, charismatic ones. For example, only $34 \%$ of the public was willing to protect an endangered spider, but $89 \%$ were willing to protect Bald Eagles (Haliaeetus leucocephalus) (Kellert 1980). Similarly, the more people perceived a species as beneficial rather than harmful to humans, the more willing they were to protect it (Opotow 1993). Because mice tend to be perceived as a nuisance, especially in the western United States, results may be different for species that are better liked. In addition, further research should investigate the extent to which findings can be generalized to other landowner populations, especially those that may be younger, less educated, or less wealthy than those who participated in our study. 


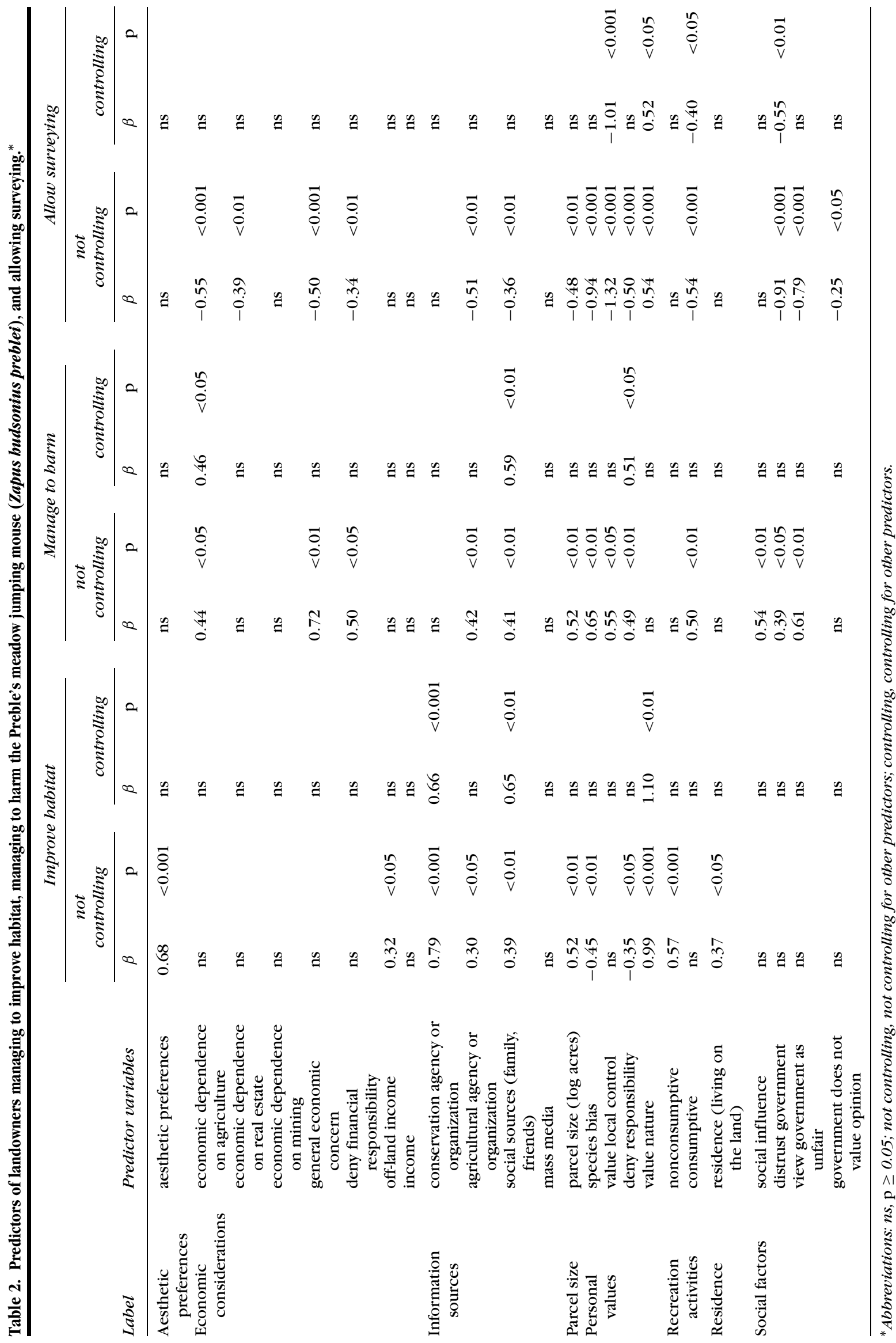


Table 3. Correlations among predictors of behavior significant in simple regressions and predictors of behavior significant in multiple regressions.

\begin{tabular}{|c|c|c|c|c|c|c|c|c|}
\hline \multirow[b]{2}{*}{$\begin{array}{l}\text { Predictors significant } \\
\text { in at least one } \\
\text { simple regression }\end{array}$} & \multicolumn{8}{|c|}{ Predictors significant in at least one multiple regression } \\
\hline & $\begin{array}{c}\text { economic } \\
\text { dependence } \\
\text { on agriculture }\end{array}$ & $\begin{array}{l}\text { information } \\
\text { from } \\
\text { conservation } \\
\text { organizations }\end{array}$ & $\begin{array}{l}\text { information } \\
\text { from } \\
\text { social } \\
\text { sources }\end{array}$ & $\begin{array}{c}\text { value } \\
\text { local } \\
\text { control }\end{array}$ & $\begin{array}{c}\text { deny } \\
\text { responsibility }\end{array}$ & $\begin{array}{l}\text { value } \\
\text { nature }\end{array}$ & $\begin{array}{l}\text { consumptive } \\
\text { recreation }\end{array}$ & $\begin{array}{c}\text { distrust } \\
\text { government }\end{array}$ \\
\hline Aesthetic preferences & -0.001 & 0.09 & 0.10 & $0.14^{a}$ & $-0.11^{a}$ & $0.45^{c}$ & 0.09 & -0.04 \\
\hline $\begin{array}{l}\text { Economic dependence } \\
\text { on agriculture }\end{array}$ & 1 & $0.17^{b}$ & $0.20^{c}$ & $0.31^{c}$ & $0.16^{b}$ & 0.05 & $0.43^{c}$ & $0.19^{c}$ \\
\hline $\begin{array}{l}\text { Economic dependence } \\
\text { on real estate }\end{array}$ & -0.001 & 0.03 & -0.02 & $0.22^{c}$ & $0.22^{c}$ & $-0.21^{c}$ & 0.08 & $0.24^{c}$ \\
\hline $\begin{array}{l}\text { General economic } \\
\text { concern }\end{array}$ & $0.44^{c}$ & 0.09 & $0.19^{c}$ & $0.36^{c}$ & $0.22^{c}$ & -0.03 & $0.28^{c}$ & $0.24^{c}$ \\
\hline $\begin{array}{l}\text { Deny financial } \\
\text { responsibility }\end{array}$ & $0.16^{b}$ & 0.002 & 0.07 & $0.17^{b}$ & $0.22^{c}$ & -0.10 & 0.06 & $0.29^{c}$ \\
\hline Off-land income & -0.04 & 0.04 & -0.06 & $-0.16^{b}$ & 0.02 & 0.03 & -0.09 & 0.02 \\
\hline $\begin{array}{l}\text { Information from } \\
\text { conservation agen- } \\
\text { cies/organizations }\end{array}$ & $0.17^{b}$ & 1 & $0.27^{c}$ & 0.05 & -0.01 & $0.13^{a}$ & $0.12^{a}$ & -0.03 \\
\hline $\begin{array}{l}\text { Information from } \\
\text { agricultural agen- } \\
\text { cies/organizations }\end{array}$ & $0.37^{c}$ & $0.41^{c}$ & $0.30^{c}$ & $0.27^{c}$ & $0.11^{a}$ & 0.02 & $0.30^{c}$ & 0.09 \\
\hline $\begin{array}{l}\text { Information from social } \\
\text { sources }\end{array}$ & $0.20^{c}$ & $0.27^{c}$ & 1 & $0.15^{b}$ & -0.03 & 0.04 & $0.18^{b}$ & $0.22^{c}$ \\
\hline Parcel size & $0.58^{\mathrm{c}}$ & $0.21^{c}$ & $0.18^{b}$ & $0.18^{b}$ & $0.18^{b}$ & 0.03 & $0.33^{c}$ & $0.21^{b}$ \\
\hline Species bias & $0.19^{c}$ & $-0.15^{b}$ & 0.07 & $0.50^{c}$ & $0.29^{c}$ & $-0.35^{c}$ & $0.20^{c}$ & $0.29^{c}$ \\
\hline Value local control & $0.31^{c}$ & 0.05 & $0.15^{b}$ & 1 & $0.19^{c}$ & -0.09 & $0.33^{c}$ & $0.35^{c}$ \\
\hline Deny responsibility & $0.19^{c}$ & 0.002 & 0.03 & $0.23^{c}$ & 1 & $-0.29^{c}$ & $0.11^{a}$ & $0.30^{c}$ \\
\hline Value nature & 0.05 & $0.13^{a}$ & 0.04 & -0.09 & $-0.37^{c}$ & 1 & $0.16^{\mathrm{b}}$ & $-0.22^{c}$ \\
\hline $\begin{array}{l}\text { Nonconsumptive } \\
\text { recreation }\end{array}$ & $0.17^{b}$ & $0.25^{c}$ & $0.15^{b}$ & -0.08 & $-0.19^{c}$ & $0.46^{c}$ & $0.29^{c}$ & -0.04 \\
\hline Consumptive recreation & $0.43^{c}$ & $0.12^{a}$ & $0.18^{b}$ & $0.33^{c}$ & $0.11^{a}$ & $0.16^{b}$ & 1 & $0.15^{b}$ \\
\hline Residence & $0.16^{b}$ & $0.11^{a}$ & 0.09 & -0.02 & $-0.11^{a}$ & $0.27^{c}$ & $0.11^{a}$ & -0.02 \\
\hline Social influence & $0.20^{c}$ & $0.13^{a}$ & $0.16^{b}$ & $0.29^{c}$ & 0.04 & $0.17^{b}$ & $0.18^{b}$ & 0.09 \\
\hline Distrust government & $0.19^{c}$ & -0.03 & $0.22^{c}$ & $0.35^{c}$ & $0.18^{b}$ & $-0.22^{c}$ & $0.15^{b}$ & 1 \\
\hline $\begin{array}{l}\text { View government as } \\
\text { unfair }\end{array}$ & $0.25^{c}$ & -0.02 & $0.22^{c}$ & $0.44^{c}$ & $0.16^{b}$ & $-0.12^{a}$ & $0.17^{b}$ & $0.50^{c}$ \\
\hline $\begin{array}{l}\text { Government does not } \\
\text { value opinion }\end{array}$ & -0.02 & $-0.14^{b}$ & -0.03 & -0.03 & $0.12^{a}$ & -0.10 & -0.04 & $0.19^{c}$ \\
\hline
\end{tabular}

$a_{p}<0.05$.

${ }^{b} p<0.01$.

${ }^{c} p<0.001$.

It was surprising that some property owners reported both managing to improve habitat and managing to harm the mouse, that these behaviors were positively rather than negatively correlated. Further, the effects of the predictors were not always opposite for these two dependent variables. This makes sense because some variables such as information may empower landowners to act, whether for good or bad. Another possible explanation for this positive relationship is that some landowners may have managed different parts of their land for different purposes, perhaps because of ambivalence about the Preble's mouse. The positive relationship between helping and harming the mouse may also reflect landowners misinterpreting "improving habitat" to mean modifying habitat for agriculture or real estate development. Future studies should ask more clearly opposing questions. For example, Have you managed your land to increase (decrease) the chance of the Preble's living on it? However, the validity of the questions about helpful versus harmful behavior is bolstered by their correlating with respondents' specific land-management practices that could benefit or harm the Preble's.

Although our study's findings may be limited by some factors, they were consistent with previous research on landowner behavior. All the predictors included in past studies, when tested individually, significantly determined the three landowner responses we examined. Moreover, when we tested these predictors simultaneously, we were able to identify those that directly determined landowners' responses. Specifically, aesthetic preferences, parcel size, and residence no longer explained landowner's responses when the remaining predictors were included. In contrast, information sources and personal values continued to explain both pro- and anticonservation responses by landowners. In addition, economic dependence on agriculture, social factors (namely 
the perception of government as untrustworthy), and consumptive recreation continued to explain the anticonservation measures of managing to eliminate the Preble's and refusing to allow surveying. Our results therefore suggest that these immediate determinants of landowners' responses should be the focus of interventions.

We need to learn about the direct and indirect relations between these variables. Structural equation modeling lends itself to this type of analysis, but we could not use it because of the nature of our variables and their distributions (Hoyle 1995; Klem 1999). It is possible that some of the variables that did not directly predict landowners' responses were actually "causes" of variables that did. For example, if valuing aesthetics causes one to value nature $(r=0.45, p<0.001)$ and this in turn causes conservation behaviors, the importance of aesthetic values would be obscured. Such detailed analyses of mechanisms of the effects of predictors were not possible in this study, but they need to be explored.

Findings with regard to information sources suggest the need to increase the dissemination of information promoting conservation and to counter information discouraging conservation. In particular, conservation agencies and organizations need to work with social networks that appear to be disseminating information that both enhances and reduces support for conservation among landowners. Individuals could be provided with information highlighting the importance of rare species' habitat (like the Preble's river corridors) for conserving other species that landowners care about or for providing ecosystem services (Hawken et al. 1999) such as erosion control. Messages directed at landowners should highlight these and other aspects of nature that they value because valuing nature was associated with both managing to improve Preble's habitat and allowing biological surveying.

Findings with regard to information sources also suggest that disseminating conservation information through social networks is more effective than doing so through mass media or direct mailings. This is consistent with sociological research on diffusion of innovations (West et al. 1988; Rogers 1995), which supports disseminating information through existing social networks and involving respected peers. Using the one-on-one diffusion approach, for example, the U.S. Extension Service has successfully promoted the adoption of agricultural innovations and could apply this approach to encouraging wildlife conservation and working with nonagricultural landowners. This approach may also be suitable for those landowners willing to engage in conservation but without the experience or resources to research conservation practices.

The economic concerns of agricultural landowners should also be addressed so they will not be motivated to harm protected species as they did in the Preble's case. Economic concerns may be alleviated by providing information about how landowners can benefit financially from conservation or by offering compensation for costs associated with conservation (Hudson 1994). For example, information could be provided about how protecting stream habitat also protects valuable water resources, or landowners might be compensated for the cost of fencing to keep cows away from streams.

Contrary to popular assertions (as reviewed by Theodori et al. 1998; Holsman 2000), our results did not support the notion that engaging in nonconsumptive or consumptive recreation leads landowners to engage in stewardship behaviors. In fact, landowners who engaged in consumptive recreation were less likely to allow surveying for the Preble's than those who did not. This suggests the need for communicating with landowners who hunt and fish about the need to permit surveys for threatened nongame species. Local hunting and fishing clubs and their spokespersons may offer a means to accomplish this goal.

Findings with regard to social factors were consistent with past research showing that distrust between government and landowners discourages conservation (Peterson \& Horton 1995) and that perceived fairness encourages cooperation between individuals and groups (reviewed by Tyler \& Smith 1998). These findings suggest that to build trust and increase perceived fairness, moving from the current top-down regulatory approach to a collaborative decision-making process is essential. Collaborative processes that involve equal-status interactions and shared power promote feelings of group membership that build trust between conflicting groups (reviewed by Brewer \& Brown 1998; Opotow \& Brook 2004), lead to a perception of government decision-making as fair (Tyler \& Lind 1992), and help achieve conservation goals (Wondolleck \& Yaffee 2000).

Collaborative processes can also improve the amount and type of information shared because collaborations provide landowners with an opportunity to learn about conservation from experts and give experts insight into private property owners' unique knowledge. Listening to landowners also reinforces the message that they are respected partners in conservation, and it may lead those who deny landowner responsibility for conservation to accept it. This should encourage conservation, because denying responsibility was associated with managing to harm the Preble's. This finding is consistent with Schwartz's (1977) altruism model, which suggests that helping others is most likely when people accept responsibility to help.

Furthermore, collaborative processes increase perceived control, which in turn leads to decision-making processes being perceived as fair (Tyler \& Lind 1992). In the case of the Preble's this may be especially important because our results and those of previous researchers (e.g., Reading et al. 1994) suggest that a sense of control is especially important to landowners. In our study, valuing local control was strongly associated with refusing to 
allow surveying. Conceivably, this response occurred because the ESA denies landowners the control they seek, so they react against it by refusing to cooperate with regulators. This conclusion is supported by psychological research on "reactance," which suggests that individuals sometimes seek to restore their freedom by violating restrictions imposed on them by others (Brehm 1966). If this is the case, then a species-protection process that enhances rather than denies landowners' feelings of control should reduce the likelihood that landowners will impede conservation of rare species. Further research is needed to test this hypothesis because our study did not directly measure the discrepancy between the amount of control landowners seek and the amount of control that they perceive as provided by the ESA.

Psychological literature suggests that one of the most effective methods for encouraging cooperation is to remove opportunities for partners to violate trust (Caporael et al. 1989). Individuals believe others will act to benefit them if they lack incentives or opportunities to do otherwise. Thus, another possible approach to enhancing trust is to institutionalize assurances that landowners will not be harmed by managing their land to help rare species. Indeed, many recent changes to the ESA, including "safe harbor," "no surprises," and "candidate conservation agreements" have this goal (Fisher 1996; Bean \& Wilcove 1997; Environmental Defense Fund 1999). Although critics complain that these plans provide inadequate protection for rare species (Honnold et al. 1997), our findings suggest that reducing landowners' fears of exploitation by regulators may be necessary to encourage behaviors desired by government policies.

\section{Acknowledgments}

We thank S. Yaffee, two anonymous reviewers, and this journal's editors for their helpful suggestions. This research was funded by a U.S. Environmental Protection Agency STAR graduate fellowship (U-915228-01-0) awarded to A.B.

\section{Literature Cited}

Bean, M. J., and D. S. Wilcove. 1997. The private-land problem. Conservation Biology 11:1-2.

Benson, D. E. 1991. Values and management of wildlife and recreation on private land in South Africa. Wildlife Society Bulletin 19:497-510.

Bliss, J. C., and A. J. Martin. 1989. Identifying NIPF management motivations with qualitative methods. Forest Science 35:601622.

Bourke, L., and A. E. Luloff. 1994. Attitudes toward the management of nonindustrial private forest land. Society and Natural Resources 7:445-457

Brehm, J. W. 1966. A theory of psychological reactance. Academic Press, New York.

Brewer, M. B., and R. J. Brown. 1998. Intergroup relations. Pages 554594 in D. Gilbert, S. Fiske, G. Lindzey, editors. The handbook of social psychology. McGraw-Hill, Boston

Brook, A. 1999. Landowner responses to an Endangered Species Act listing: some recommendations for encouraging private land conservation. M.S. thesis. University of Michigan, Ann Arbor.

Caporael, L. R., R. M. Dawes, J. M. Orbell, and A. J. Van de Kragt. 1989. Selfishness examined: cooperation in the absence of egoistic incentives. Behavioral and Brain Sciences 12:683-739.

Carr, S., and J. Tait. 1991. Differences in the attitudes of farmers and conservationists and their implications. Journal of Environmental Management 32:281-294.

Dunlap, R. E., and K. D. Van Liere. 1978. The "new environmental paradigm": a proposed measuring instrument and preliminary results. Journal of Environmental Education 9:10-19.

Environmental Defense Fund. 1999. Safe harbor: helping landowners help endangered species. Environmental Defense Fund, Washington, D.C.

Erickson, D. L., and R. De Young. 1993. Management of farm woodlots and windbreaks: some psychological and landscape patterns. Journal of Environmental Systems 22:233-247.

Fisher, E. 1996. Habitat conservation planning under the Endangered Species Act: no surprises and the quest for certainty. University of Colorado Law Review 67:371-405.

Fortmann, L., and L. Huntsinger. 1989. The effects of nonmetropolitan population growth on resource management. Society and Natural Resources 2:9-22.

Green, S. B., N. J. Salkind, and T. M. Akey. 2000. Using SPSS for Windows: analyzing and understanding data. Prentice-Hall, Upper Saddle River, New Jersey.

Grieshop, J. I., E. MacMullan, S. Brush, C. Pickel, and F. G. Zalom. 1990. Extending integrated pest management by public mandate: a case study from California. Society and Natural Resources 3:33-51.

Hawken, P., A. Lovins, and L. H. Lovins. 1999. Natural capitalism: creating the next industrial revolution. Little Brown, Boston.

Haymond, J. L. 1990. Wildlife attitudes of early adopters who own forestland. Society and Natural Resources 3:11-18.

Holsman, R. H. 2000. Goodwill hunting? Exploring the role of hunters as ecosystem stewards. Wildlife Society Bulletin 28:808-816.

Honnold, D., J. A. Jackson, and S. Lowry. 1997. Habitat conservation plans and the protection of habitat: reply to Bean and Wilcove. Conservation Biology 11:297-299.

Hoyle, R. H. editor. 1995. Structural equation modeling: concepts, issues, and applications. Sage, Thousand Oaks, California.

Hudson, W. E. 1994. Building economic incentives into the Endangered Species Act. Defenders of Wildlife, Washington, D.C.

James, S. M. 2002. Bridging the gap between private landowners and conservationists. Conservation Biology 16:269-271.

Kalton, G. 1983. Introduction to survey sampling. Sage, Newbury Park, California.

Kellert, S. R. 1980. American attitudes toward and knowledge of animals: an update. International Journal for the Study of Animal Problems 1:87-119.

Klem, L. 1999. Personal communication to Amara Brook. University of Michigan Center for Statistical Consultation and Research, Ann Arbor.

Korsching, P. F, and T. J. I. Hoban. 1990. Relationships between information sources and farmers' conservation perceptions and behavior. Society and Natural Resources 3:1-10.

Kraus, S. J. 1995. Attitudes and the prediction of behavior: a metaanalysis of the empirical literature. Personality and Social Psychology Bulletin 21:58-75.

Lepkowski, J. M., and M. P. Couper. 1999. Analysis of survey data. I: Course notes. University of Michigan, Ann Arbor.

Makowski, T. J., A. J. Sofranko, and J. C. Van Es. 1990. Agroecological and policy influences on no-till adoption. Society and Natural Resources 3:361-371.

McCann, E., S. Sullivan, D. Erickson, and R. De Young. 1997. Environmental awareness, economic orientation, and farming practices: a 
comparison of organic and conventional farmers. Environmental Management 21:747-758.

Napier, T. L., and S. M. Camboni. 1988. Attitudes toward a proposed soil conservation program. Journal of Soil and Water Conservation 43:186-191.

Ochterski, J. A. 1996. Why land is protected: motivations underlying real estate donations to land conservancies. M.S. thesis. University of Michigan, Ann Arbor.

Opotow, S. 1993. Animals and the scope of justice. Journal of Social Issues 49:71-85.

Opotow, S., and A. Brook. 2004. Identity and exclusion in rangeland conflict. Pages 505-556 in S. Clayton and S. Opotow, editors. Identity and the natural environment. MIT Press, Cambridge, Massachusetts.

Osterman, D. A., and T. L. Hicks. 1988. Highly erodible land: farmer perceptions versus actual measurements. Journal of Soil and Water Conservation 43:177-182.

Peterson, T. R., and C. C. Horton. 1995. Rooted in the soil: how understanding the perspectives of landowners can enhance the management of environmental disputes. Quarterly Journal of Speech 81:139-166.

Reading, R. P., T. W. Clark, and S. R. Kellert. 1994. Attitudes and knowledge of people living in the greater Yellowstone ecosystem. Society and Natural Resources 7:349-365.

Rogers, E. M. 1995. Diffusion of innovations. The Free Press, New York. Salant, P., and D. A. Dillman. 1994. How to conduct your own survey. Wiley, New York.

Schwartz, S. 1977. Normative influences on altruism. Pages 221-279 in L. Berkowitz, editor. Advances in experimental social psychology. Academic Press, New York.

Stein, B. A., T. Breden, and R. Warner. 1995. Significance of federal lands for endangered species. Pages 398-401 in E. T. LaRoe, editor. Our living resources: a report to the nation on the distribution, abundance, and health of U.S. plants, animals, and ecosystems. U.S. National Biological Service, Washington, D.C.

Sullivan, S., E. McCann, R. De Young, and D. Erickson. 1996. Farmers' attitudes about farming and the environment: a survey of conventional and organic farmers. Journal of Agricultural and Environmental Ethics 9:123-143.

Theodori, G. L., A. E. Luloff, and F. K. Willits. 1998. The association of outdoor recreation and environmental concern: reexamining the Dunlap-Heffernan thesis. Rural Sociology 63:94-108.

Tietenberg, T. 2000. Environmental and natural resource economics. Addison-Wesley, Reading, Massachusetts.

Tyler, T. R., and E. A. Lind. 1992. A relational model of authority in groups. Advances in Experimental Social Psychology 25:115191.

Tyler, T. R., and H. J. Smith. 1998. Social justice and social movements. Pages 595-629 in D. Gilbert, S. Fiske, and G. Lindzey, editor. The handbook of social psychology. McGraw-Hill, Boston.

U.S. Fish and Wildlife Service. 1998a. Endangered and threatened wildlife and plants: final rule to list the Preble's meadow jumping mouse as a threatened species. Federal Register 63:26517-26530.

U.S. Fish and Wildlife Service. 1998b. Endangered and threatened wildlife and plants: proposed special regulations for the Preble's meadow jumping mouse. Federal Register 63:66777-66784.

U.S. Fish and Wildlife Service. 2001. Endangered and threatened wildlife and plants: final special regulations for the Preble's meadow jumping mouse. Federal Register 66:28125-28131.

U.S. Fish and Wildlife Service. 2002. Endangered and threatened wildlife and plants: designation of critical habitat for the Preble's meadow jumping mouse (Zapus hudsonius preblei); proposed rule. Federal Register 67:47154-47210.

U.S. General Accounting Office. 1994. Endangered Species Act: information on species protection on nonfederal lands. U.S. General Accounting Office, Washington, D.C.

Vogel, S. 1996. Farmers' environmental attitudes and behavior: a case study for Austria. Environment and Behavior 28:591-613.

Weicher, J. C. 1995. Changes in distribution of wealth: increasing inequality? Review: Federal Reserve Bank of St. Louis 77:5-23.

West, P. C., J. M. Fly, D. J. Blahna, and E. M. Carpenter. 1988. The communication and diffusion of NIPF management strategies. Northern Journal of Applied Forestry 5:265-270.

Wilcove, D. S., M. J. Bean, R. Bonnie, and M. McMillan. 1996. Rebuilding the Ark: toward a more effective Endangered Species Act for private land. Environmental Defense Fund, Washington, D.C.

Wondolleck, J. M., and S. Yaffee. 2000. Making collaboration work: lessons from innovation in natural resource management. Island Press, Washington, D.C.

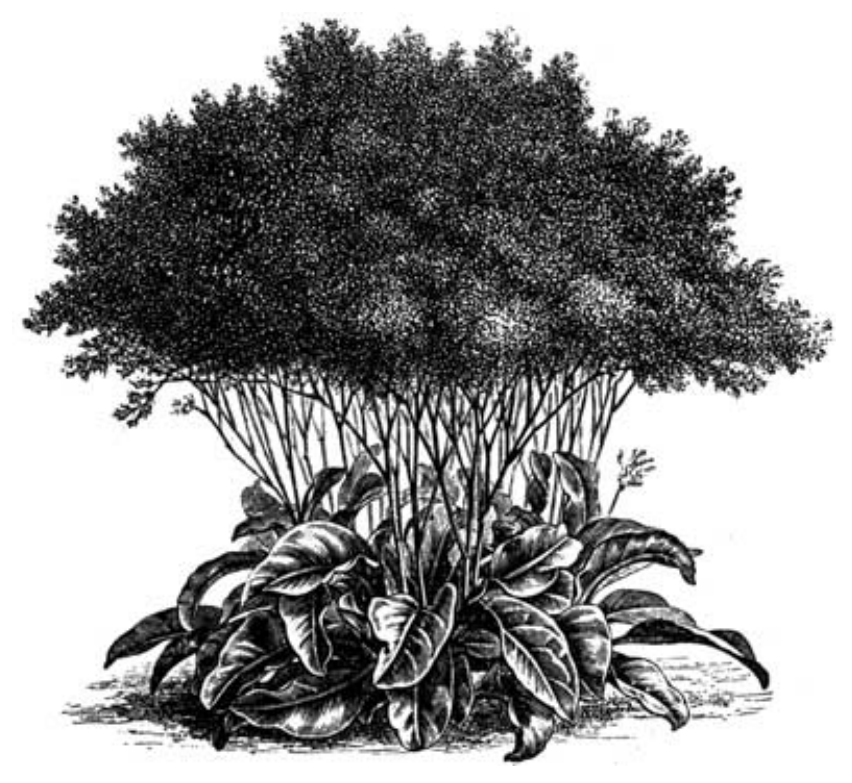

